\title{
The Possible Roles of Escherichia coli in the Nitrogen Cycle
}

\author{
Maryam Taabodi $^{1}$ [D $\cdot$ Fawzy Mohamed Hashem ${ }^{2} \cdot$ Thomas Patrick Oscar $^{3} \cdot$ Salina Parveen $^{2} \cdot$ Eric Bruce May $^{1}$
}

Received: 16 September 2018 / Revised: 17 March 2019 / Accepted: 6 April 2019 / Published online: 16 April 2019

(c) The Author(s) 2019

\begin{abstract}
This study was designed to determine the response of Escherichia coli to three different nutrient sources. In this study, E. coli was exposed to concentrations of ammonia as ammonium chloride and nitrate as sodium nitrate at $0.5,1.0$ and $2.0 \mathrm{mg} / \mathrm{L}$; and reagent grade urea at 10,20 and $30 \mu \mathrm{g} / \mathrm{L}$ using bacterial concentrations of $10^{-1}, 10^{-2}$ and $10^{-3}$ per ml. Cultures were incubated for $24 \mathrm{~h}$ at $37^{\circ} \mathrm{C}$. Samples were analyzed using a LACHET ${ }^{\mathrm{TM}}$ ( 800 Series) for ammonia-N, Nitrate-N and Urea-N which was converted to molar concentrations. Growth rates for $E$. coli were determined using serial dilutions, incubated on $3 \mathrm{M}^{\mathrm{TM}}$ Petrifilm ${ }^{\mathrm{TM}}$ for $24 \mathrm{~h}$ at $37^{\circ} \mathrm{C}$ with colony counts taken. The results showed that $E$. coli was able to utilize both ammonia and nitrate, with ammonium utilization significantly greater than nitrate. Ammonium utilization was directly proportional to concentration of ammonium chloride added and to some degree, the initial number of bacteria exposed. Nitrate utilization occurred at all concentrations and dilutions when compared with control concentrations and corresponded with concentrations of nitrate, but there was very little difference between bacterial dilutions. Urea production did occur but was unaffected by either concentration of urea or bacteria dilution. Positive growth rates were seen with ammonium with increasing growth rates as ammonium chloride concentrations were increased. Urea appeared to cause a slight decrease in growth, but nitrate was inconclusive with regard to growth.
\end{abstract}

Keywords Bacteria $\cdot$ Nutrients $\cdot$ Utilization $\cdot$ Growth

\section{Introduction}

Historical, and in many cases current, practices by agriculture is the use of animal manures as a source of nitrogen (Brooks et al. 2015). On the Delmarva Peninsula, poultry litter has been and is currently a primary source of fertilizer (Han et al. 2015). Since all manures contain both pathogenic and harmless bacteria, the practice results in the additional loading of bacteria to the soil which has been shown to alter community diversity (Chu et al. 2007; Lv et al. 2017). The effect that this may have on nitrogen cycling is uncertain as few studies are available that addresses specific bacterial

Maryam Taabodi

mtaabodi@umes.edu

1 Department of Natural Sciences, University of Maryland Eastern Shore, Princess Anne, MD, USA

2 Department of Agriculture, Food and Resource Sciences, University of Maryland Eastern Shore, Princess Anne, MD, USA

3 USDA-ARS, University of Maryland Eastern Shore, Princess Anne, MD, USA response to nitrogen sources (Geisseler et al. 2010) and conversely the effect of manures and nitrogen sources on community structure is rarely available (Enwall et al. 2007). At present, we are applying metagenomics to understand the response of microbial communities to changes in agricultural practice and transcriptomics to examine the potential effect on community function (Yergeau et al. 2015; Abreu and Taga 2016). Concurrently and specific to this paper, we are isolating bacteria from agricultural drainage ditches for use in determining their response to nitrogen sources. It is felt that using these two approaches will allow for a better understanding of how changing agricultural practices may affect microbial communities and the implications for water quality (Guo et al. 2014).

There is little dispute regarding the role of bacteria and other microbes in the cycling of nitrogen in soils, water or sediments (Stein and Klotz 2016) and the important role they play in agricultural systems including sediments of agricultural drainage ditches (Maeda et al. 2011; Kostadinova et al. 2014). With increased reliance on amended nitrogen either as ammonia- $\mathrm{N}$, nitrate- $\mathrm{N}$, or urea- $\mathrm{N}$ the environmental impacts due to ground and surface runoff are well 
documented (Wang et al. 2012; Zhou et al. 2013). Many approaches to remediate the problem have been attempted and are based on providing carbon as a source for bacterial growth (Christianson et al. 2017). On the Delmarva Peninsula, poultry litter has been the primary fertilizer for corn and other crops (Howarth et al. 2002; Glibert et al. 2006), and contains Urea-N at $3 \%$ by weight on the average (Bolan et al. 2010). Nationally, there has been a shift from use of ammonia-N, nitrate-N, or poultry litter to synthetic urea-N due to economic and legislative pressures (Cahill et al. 2007; Gao et al. 2014). The effect of changing nitrogen source and the long-term impacts of artificial fertilizer and animal manures on sediments and water in drainage ditches are not clearly understood. However, studies have shown that community structure does change due to shifts in type of nitrogen source and method of application (Wang et al. 2012).

For this study, we have chosen Escherichia coli because recent surveys on the Eastern Shore of the Delmarva Peninsula have shown that $E$. coli is a frequent isolate in surface waters and ditch sediments adjacent to agricultural fields (unpublished data). E. coli is easily grown and used experimentally under a variety of conditions (Williams and Marco 2014; Côté et al. 2016). It is a facultative anaerobe present in the guts of many vertebrates (O'Toole 2011; Babujee et al. 2012) and in particular present in poultry litter (Metcalf et al. 2014) which is the primary source of fertilizer for the Delmarva Peninsula (Pechal et al. 2014; Kleinman et al. 2015). The role of $E$. coli in the nitrogen cycle is uncertain (Shimizu 2013; Wang et al. 2017), but it is an ubiquitous environmental bacterium known to be urease negative (Konieczna et al. 2012) but, under some conditions shown to be urease positive (Zhang and Chen 2015). It has been shown to be highly plastic genetically, altering its ability to utilize nitrogen under changing environmental conditions (Grossman et al. 1993). However, most studies have been conducted in the guts of vertebrates and few have been conducted on E. coli as an environmental microbe (Allison et al. 2014). The purpose of this study was to evaluate the response of $E$. coli to media consisting of water and three different nitrogen sources.

\section{Methods}

\section{E. coli Source}

A pure culture of $E$. coli was obtained from the American Type Culture Collection (ATCC ${ }^{\circledR} 25922^{\mathrm{TM}}$ ) and stored at University of Maryland Eastern Shore (UMES). The sample was thawed and inoculated in $10 \mathrm{ml}$ of buffered peptone water (BPW) and incubated, at $37^{\circ} \mathrm{C}$ for $24 \mathrm{~h}$ and used for this study.

\section{Determination of Growth Rate}

Tenfold serial dilutions of $E$. coli from the stock solution were made ranging from $10^{0}$ to $10^{-10}$ with $1.0 \mathrm{ml}$ from each dilution plated on $3 \mathrm{M}^{\mathrm{TM}}$ Petrifilm ${ }^{\mathrm{TM}}$. The Petrifilms were incubated at $37^{\circ} \mathrm{C}$ for $24 \mathrm{~h}$ and colonies counted using standard plate count method to create a dilution curve. To determine the effect of each nutrient on growth $1.0 \mathrm{ml}$ was taken from each treated tube, incubated at $37{ }^{\circ} \mathrm{C}$ for $24 \mathrm{~h}$ then plated on Petrifilm ${ }^{\mathrm{TM}}$ with the film incubated at the previous temperature and time and colony forming units (CFU's) enumerated. The CFU's were then used to measure the amount of growth. In those cases where the number of bacteria were too numerus to count (TNTC) or had no growth the data is not reported. Growth is reported for the bacterial dilutions of $10^{-1}, 10^{-2}, 10^{-3}$ and $10^{-4}$ only. At the $10^{0}$ dilution CFU's were TNTC and at dilutions above $10^{-3}$ no CFU's were seen. The dilution curve samples were without nutrient, nutrient addition and used as controls for growth comparisons.

\section{Response to Nutrient Source}

Based on previous work with the $E$. coli growth, we used dilutions of $10^{-1}, 10^{-2}$ and $10^{-3}$ bacteria per $\mathrm{ml}$. For nitrogen source, we used concentrations of $0.5,1.0$, and $2.0 \mathrm{mg} / \mathrm{L}$ ammonium chloride which resulted in $0.59,1.14$ and $2.21 \mathrm{mg} / \mathrm{L}$ ammonia- $\mathrm{N}$, respectively. This was then converted to molecular ammonium yielding concentrations of $0.72,1.47$ and $2.85 \mathrm{mg} / \mathrm{L}$ ammonium. Sodium nitrate was also used at concentrations of $0.5,1.0$, and $2.0 \mathrm{mg} / \mathrm{L}$ and converted to molecular nitrate resulting in concentrations of $2.12,4.34$ and $8.63 \mathrm{mg} / \mathrm{L}$ nitrate, respectively. Urea as Ultra Urea ${ }^{\mathrm{TM}}$ (Invitrogen Inc., Massachusetts, USA) at concentrations of 10,20 and $30 \mathrm{mg} / \mathrm{L}$ urea resulted in urea-N at 3.3, 10.0 and $19.0 \mu \mathrm{g} / \mathrm{L}$ urea, respectively. When converted to molecular urea with the resulting concentrations of $14.62,44.30$ and $81.47 \mu \mathrm{g} / \mathrm{L}$, respectively. These concentrations are consistent with those observed in the field (Kibet et al. 2016; King et al. 2017). Controls for each nutrient and nutrient concentration without bacteria were also analyzed. These controls served as internal standards during analysis.

All exposures were in triplicate and tubes incubated at $37^{\circ} \mathrm{C}$ for $24 \mathrm{~h}$. The $24 \mathrm{~h}$ incubation time was chosen as $E$. coli is known to be in its stationary phase after $16 \mathrm{~h}$ and thus this would represent the maximum concentration of organisms per $\mathrm{ml}$ at the time of counting (Chubukov and Sauer 2014). After $24 \mathrm{~h}$ all tubes were placed on ice to arrest further activity and taken to the Nutrient Management Laboratory where they were agitated and split into 
two sub-samples. The first was filtered using paper filters $(0.45 \mu \mathrm{m})$ for ammonia- $\mathrm{N}$ and nitrate-N analyses and the second with glass filters $(0.45 \mu \mathrm{m})$ for urea-N. Filtered samples were stored at $4{ }^{\circ} \mathrm{C}$ and analyzed within $24 \mathrm{~h}$ of collection. The concentrations of, ammonia-N, nitrate-N and urea-N were determined on filtered samples using a LACHAT $^{\text {TM }}$ QuickChem (800 series) method 10-115-011-A. Utilization for the $24 \mathrm{~h}$ period for ammonium and nitrate were calculated by subtracting the final concentration from the control concentration. Production for the $24 \mathrm{~h}$ period for urea was calculated by subtracting the control concentration from the final concentration. All results are reported as molecular concentrations of ammonium, nitrate and urea.

\section{Statistical Analyses}

The data were assessed by two-way ANOVA using a 4 by 3 factorial design (version 6.0, Prism, GraphPad Software, San Diego, CA). To better understand these interactions, two means comparison tests were done.

\section{Results and Discussion}

\section{Growth and Nutrient Utilization After $24 \mathrm{~h}$ Ammonium Chloride Exposure}

When the final concentrations of ammonium were subtracted from the control, it showed that $E$. coli utilized ammonium. The amount of ammonium utilized correlated with bacterial dilutions and ammonium concentrations in the media between 0.72 and $1.47 \mathrm{mg} / \mathrm{L}$ where utilization increased, but between 1.47 and $2.85 \mathrm{mg} / \mathrm{L}$ there was no significant difference (Fig. 1a). At molar concentrations of ammonium of $0.72,1.47$ and $2.85 \mathrm{mg} / \mathrm{L}$ the amount of ammonium utilized at $0.72 \mathrm{mg} / \mathrm{L}$ was $0.72 \pm 0.01,0.35 \pm 0.02$ and $0.11 \pm 0.02 \mathrm{mg} / \mathrm{L}$ at dilutions of $10^{-1}, 10^{-2}$ and $10^{-3}$, respectively. At $1.47 \mathrm{mg} / \mathrm{L}$ utilization was $1.00 \pm 0.32,0.63 \pm 0.02$ and $0.32 \pm 0.01 \mathrm{mg} / \mathrm{L}$ of ammonium and at $2.85 \mathrm{mg} / \mathrm{L}$ of ammonium utilization was $1.03 \pm 0.01,0.60 \pm 0.18$ and $0.21 \pm 0.09$ at bacterial dilutions of $10^{-1}, 10^{-2}$ and $10^{-3}$, respectively. After $24 \mathrm{~h}$, colony counts for dilutions of $10^{-1}$ was TNTC at all concentrations of ammonium. At $10^{-2}$ colony counts were 230,360 and 430 CFU's at concentrations of $0.72,1.47$ and $2.85 \mathrm{mg} / \mathrm{L}$ ammonium in the media, respectively. At $10^{-3} \mathrm{CFU}$ 's were 39,45 and 57 at the above concentrations. At $10^{-4}$ and $10^{-5}$ colony counts were too low to be meaningful. This suggests that ammonium may have a positive influence on $E$. coli growth.

These findings are consistent with those of other authors (Peterson et al. 2005; Shimizu 2013; Brown et al. 2014; Wasik and Chmielowski 2017) where E. coli was able to
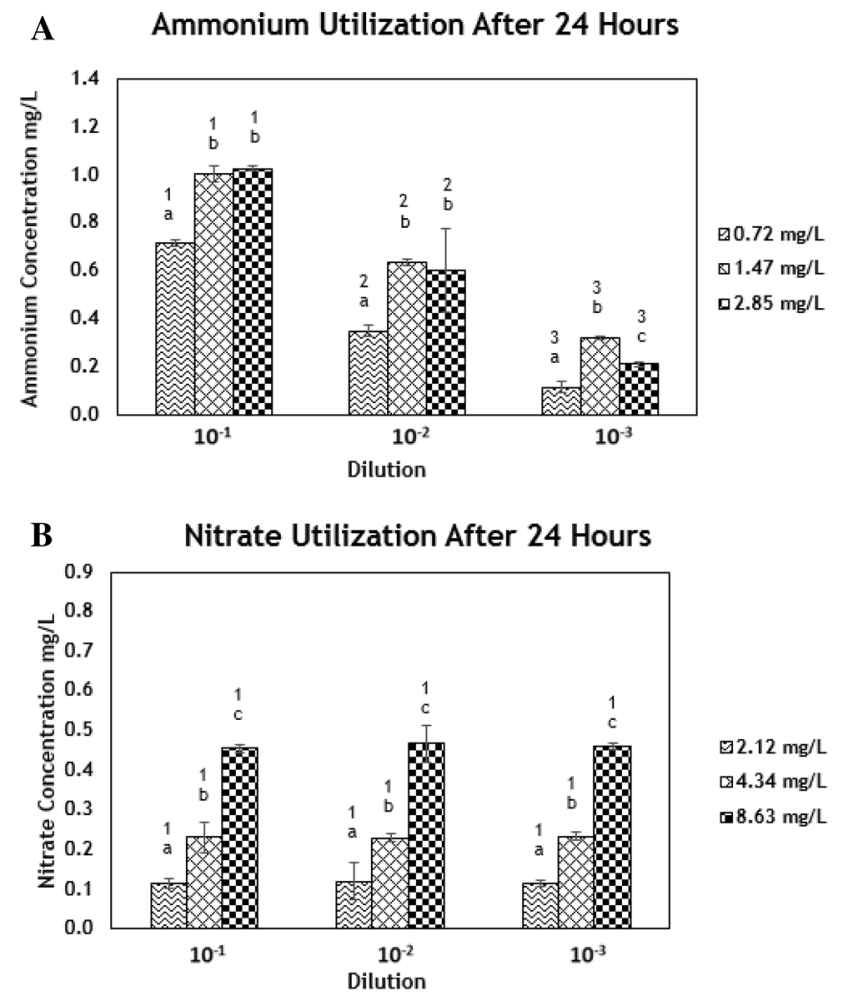

C Urea Production After 24 Hours

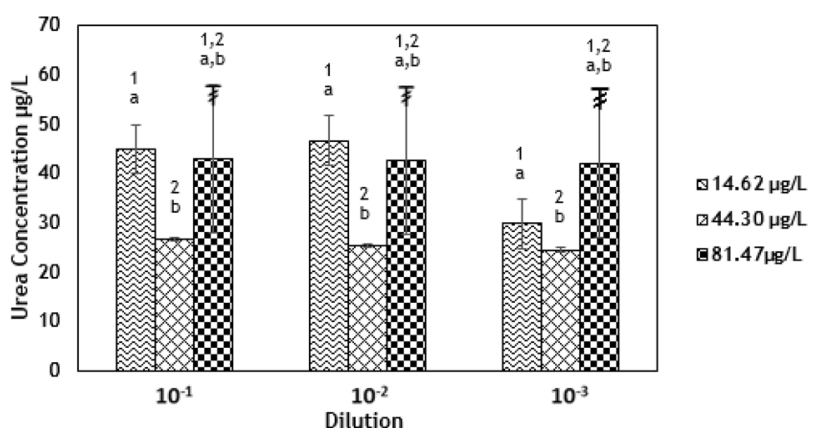

Fig. 1 a Ammonium utilization after $24 \mathrm{~h}$ incubation for exposures of $0.72,1.47$ and $2.85 \mathrm{mg} / \mathrm{L}$ ammonium at bacterial dilutions of $10^{-1}, 10^{-2}$ and $10^{-3}$. Utilization was calculated by subtracting control concentrations from final concentrations. Letter designations denote significance $(P<0.05)$ between concentrations at each bacterial dilution and number designations significance $(P<0.05)$ between bacterial dilutions for each ammonium concentration. b Nitrate utilization after $24 \mathrm{~h}$ incubation for exposures of $2.12,4.34$ and $8.63 \mathrm{mg} / \mathrm{L}$ nitrate at bacterial dilutions of $10^{-1}, 10^{-2}$ and $10^{-3}$. Utilization was calculated by subtracting control concentrations from final concentrations. Letter designations denote significance $(P<0.05)$ between concentrations at each bacterial dilution and number designations significance $(P<0.05)$ between bacterial dilutions for each nitrate concentration. $\mathbf{c}$ Urea production after $24 \mathrm{~h}$ incubation for exposures of $14.62,44.30$ and $81.47 \mu \mathrm{g} / \mathrm{L}$ urea at bacterial dilutions of $10^{-1}, 10^{-2}$ and $10^{-3}$. Production was calculated by subtracting final concentrations from control concentrations. Letter designations denote significance $(P<0.05)$ between concentrations at each bacterial dilution and number designations significance $(P<0.05)$ between bacterial dilutions for each urea concentration. For urea at $81.47 \mathrm{mg} / \mathrm{L}$ the broken line ( $¥)$ indicates that the variance was too great to be shown in the graph entirely as error bars 
reduce ammonium concentrations under varying conditions. For example, Wasik and Chmielowski (2017) demonstrated that in filter material used for domestic sewage filtration, ammonium reduction by $E$. coli was observed, but not to the degree as seen in this study. Nygaard et al. (2006) clearly demonstrated that because $E$. coli had the ammonium transporter B (AmtB) protein it was capable of assimilating ammonium. This was further supported by Yuan et al. (2009) who demonstrated that E. coli was able through a variety of enzymatic pathways to assimilate and incorporate ammonium in many of its proteins, particularly glutamate. Most of the studies were related to animals and sewage and not $E$. coli as a constituent of the environment. The results from this study would suggest that as a constituent of the sediment microbial community $E$. coli would be involved in the conversion of ammonium to amino acids and that ammonium appeared to promote growth.

\section{Growth and Nutrient Utilization After $24 \mathrm{~h}$ Sodium Nitrate Exposure}

When sodium nitrate was added to the medium the final concentrations were $2.12,4.34$ and $8.63 \mathrm{mg} / \mathrm{L}$ nitrate. However, after bacteria were exposed there was a marked decrease in nitrate but no significant difference between bacterial dilutions (Fig. 1B). At $2.12 \mathrm{mg} / \mathrm{L}$ utilization was $0.11 \pm 0.00$, $0.12 \pm 0.04$ and $0.12 \pm 0.02$ and at $4.34 \mathrm{mg} / \mathrm{L}$ utilization was $0.23 \pm 0.37,0.23 \pm 0.09$ and $0.23 \pm 0.01 \mathrm{mg} / \mathrm{L}$. At $8.63 \mathrm{mg} / \mathrm{L}$ utilization was $0.45 \pm 0.12,0.47 \pm 0.05$ and $0.46 \pm 0.01$ and growth data for E. coli was less consistent than that seen with ammonium. At $10^{-1}$ the CFU was TNTC at all nitrate concentrations. At 2.12, 4.43 and $8.63 \mathrm{mg} / \mathrm{L}$ CFU's were 430, 260 and 540, respectively, for $10^{-2}$ bacterial dilution while at $10^{-3}$ was 32,46 and 105 CFU's.

At all concentrations and bacterial dilutions there was a significant reduction in nitrate with coincident utilization of nitrate. In this study, this specific strain of E. coli did not show any variation in utilization between dilutions but did vary with exposure concentrations. It is known that specific strains of $E$. coli do vary in having nitrate reductase which is most active under anaerobic conditions (Potter et al. 1999). Similarly, authors have shown that anaerobic conditions may be important as triggers to nitrate reductase, hence nitrate utilization (Ishimoto and Yamamoto 1977; Noguchi et al. 1997; Whitehead and Cole 2006; Warry et al. 2008; van Beilen and Hellingwerf 2016). Again, the type of strain used may play a significant role as nitrate utilization is strain specific. Our concern is the lack of information for E. coli regarding its role in nitrate utilization. In this study, there is no indication that $E$. coli growth correlated with nitrate concentrations as the CFU's fluctuated too much to draw any real conclusion.

\section{Growth and Nutrient Production After 24 h Urea Exposure}

Urea concentrations were higher than controls suggesting that $E$. coli produces urea. When the control concentrations of urea were subtracted from the final concentrations resulting production after $24 \mathrm{~h}$ at $14.62 \mu \mathrm{g} / \mathrm{L}$ was $44.94 \pm 133.65$, $46.74 \pm 133.26$ and $29.81 \pm 82.33 \mu \mathrm{g} / \mathrm{L}$ at dilutions of $10^{-1}$, $10^{-2}$ and $10^{-3}$, respectively (Fig. 1c). Urea production was lower at $44.3 \mu \mathrm{g} / \mathrm{L}$ with production of urea at $26.80 \pm 0.36$, $25.39 \pm 1.28$ and $24.57 \pm 4.10 \mu \mathrm{g} / \mathrm{L}$ at $10^{-1}, 10^{-2}$ and $10^{-3}$, respectively. At $81.7 \mu \mathrm{g} / \mathrm{L}$ urea production was $42.87 \pm 4.99$, $42.66 \pm 3.49$ and $42.19 \pm 3.27$ at bacterial dilutions of $10^{-1}$, $10^{-2}$ and $10^{-3}$, respectively. E. coli growth on Petri films for urea at $10^{-1}$ was TNTC. At $10^{-2}$ CFU's were 372,372 and 411 at concentrations of $14.62,44.30$ and $81.47 \mu \mathrm{g} / \mathrm{L}$ urea, while at $10^{-3} \mathrm{CFU}$ 's were 40,1 and 2 . Below the $10^{-3}$ dilution CFU's were too low to be meaningful.

At all concentrations of exposure there was urea production. It has been shown that under some conditions E.coli will produce urea (Morris and Koffron 1967; Tuchman et al. 1997). This study confirmed previous studies that urea is produced. While, between 14.62 and $44.3 \mu \mathrm{g} / \mathrm{L}$ urea in media there was a decrease at all bacterial dilutions in urea production. This could represent a negative feedback with the higher concentration of urea slowing production. This is consistent between all bacterial dilutions. However, between 44.3 and $81.47 \mu \mathrm{g} / \mathrm{L}$ urea production significantly increased with the higher concentration. When it was exposed to $81.47 \mu \mathrm{g} / \mathrm{L}$ urea there was a significant fluctuation in urea production which makes these results somewhat unreliable but still shows urea production at this concentration. There is some suggestion urea decreases $E$. coli growth but the evidence is not strong. It has been shown that urea is toxic at higher concentrations (Muema et al. 2015; Soman et al. 2017) and thus the possibility exists that our exposure rates caused a reduction in growth which also may influence any utilization of urea.

\section{Conclusion}

The results of this study clearly show that as a potential environmental microbe $E$. coli utilizes ammonium and that utilization corresponded to concentrations of ammonium and the number of $E$. coli per $\mathrm{ml}$ of media. On the other hand, $E$. coli utilizes nitrate but that neither concentration of nitrate or bacterial dilution appear to affect the amount of utilization. Urea was produced by E. coli under the conditions of this study. In the case of urea there was some suggestion that growth was diminished but these results are not conclusive. The implications of this study are that bacteria can be exposed to varying nitrogen sources and conclusions drawn 
regarding their potential role in the environment, as well as the effect of specific nitrogen sources on $E$. coli growth. In this case, it is important to know the potential role of $E$. coli as we continue to construct systems designed to reduce nitrates in agricultural ditches.

Acknowledgements The authors thank the urea project funded under the USDA-NIFA Grant \# 2015-38821-24380 for the financial support for this study.

\section{Compliance with Ethical Standards}

Conflict of Interest On behalf of all authors, the corresponding author states that there is no conflict of interest.

Open Access This article is distributed under the terms of the Creative Commons Attribution 4.0 International License (http://creativeco mmons.org/licenses/by/4.0/), which permits unrestricted use, distribution, and reproduction in any medium, provided you give appropriate credit to the original author(s) and the source, provide a link to the Creative Commons license, and indicate if changes were made.

\section{References}

Abreu NA, Taga ME (2016) Decoding molecular interactions in microbial communities. FEMS Microbiol Rev 40(5):648-663

Allison SD, Chacon SS, German DP (2014) Substrate concentration constraints on microbial decomposition. Soil Biol Biochem 79:43-49

Babujee L, Apodaca J, Balakrishnan V, Liss P, Kiley PJ, Charkowski AO, Glasner JD, Perna NT (2012) Evolution of the metabolic and regulatory networks associated with oxygen availability in two phytopathogenic enterobacteria. BMC Genom 13:110

Bolan NS, Szogi AA, Chuasavathi T, Seshadri B, Rothrock MT Jr, Panneerselvam P (2010) Uses and management of poultry litter. World's Poult Sci J 66:673-698

Brooks JP, Gerba CP, Pepper IL (2015) Land application of organic residuals: municipal biosolids and animal manures. Environ Microbiol (Third edition) 607-621

Brown DR, Barton G, Pan Z, Buck M, Wigneshweraraj S (2014) Nitrogen stress response and stringent response are coupled in Escherichia coli. Nat Commun 5:4115

Cahill S, Osmond D, Crozier C, Israel D, Weisz R (2007) Winter wheat and maize response to urea, ammonium nitrate and a new urea formaldehyde polymer fertilizer. Agron J 99:1645-1653

Christianson LE, Collick AS, Bryant RB, Rosen T, Bock EM, Allen AL, Kleinman PJA, May EB, Buda AR, Robinson J, Folmar GJ, Easton ZM (2017) Enhanced denitrification bioreactors hold promise for mid-Atlantic ditch drainage. Agric Environ Lett 2(1): 170032

Chu H, Lin X, Fujii T, Morimoto S, Yagi K, Hu J, Zhang J (2007) Soil microbial biomass, dehydrogenase activity, bacterial community structure in response to long-term fertilizer management. Soil Biol Biochem 39(11):2971-2976

Chubukov V, Sauer U (2014) Environmental dependence of stationaryphase metabolism in Bacillus subtilis and Escherichia coli. Appl Environ Microbiol 80(9):2901-2909

Côté JP, French S, Gehrke SS, MacNair CR, Mangat CS, Bharat A, Brown ED (2016) The genome-wide interaction network of nutrient stress genes in Escherichia coli. MBio 7(6):e01714-e01716
Enwall K, Nyberg KA, Bertilsson S, Cederlund H, Stenström J, Hallin S (2007) Long term impact of fertilization on activity and composition of bacterial communities and metabolic guilds in agricultural soil. Soil Biol Biochem 39(1):106-115

Gao Y, He N, Zhang X (2014) Effects of reactive nitrogen deposition on terrestrial and aquatic ecosystems. Ecol Eng 70:312-318

Geisseler D, Horwath WR, Joergensen RG, Ludwig B (2010) Pathways of nitrogen utilization by soil microorganisms - a review. Soil Biol Biochem 42(12):2058-2067

Glibert PM, Harrison J, Heil C, Seitzinger S (2006) Escalating worldwide use of UEA - a global change contributing to coastal eutrophication. Biogeochemistry 77:441-463

Grossman AR, Schaefer MR, Chiang GG, Collier JL (1993) The phycobilisome, a light-harvesting complex responsive to environmental conditions. Microbiol Rev 57(3):725-749

Guo M, Huang K, Chen S, Qi X, He X, Cheng W, Luo Y, Xia K, Xu W (2014) Combination of metagenomics and culture-based methods to study the interaction between ochratoxin and gut microbiota. Toxicol Sci 141(1):314-323

Han K, Kleinman PJ, Saporito LS, Church C, McGrath JM, Reiter MS, Tingle SC, Allen AL, Wang LQ, Bryant RB (2015) Phosphorus and nitrogen leaching before and after tillage and urea application. J Environ Qual 44(2):560-571

Howarth RW, Boyer EW, Pabich WJ, Galloway JN (2002) Nitrogen use in the United States from 1961-2000 and potential future trends. AMBIO 31(2):88-96

Ishimoto M, Yamamoto I (1977) Cell growth and metabolic products of Escherichia coli in nitrate respiration. J Basic Microbiol 17(4):309-320

Kibet LC, Bryant RB, Buda AR, Kleinman PJ, Saporito LS, Allen AL, Hashem FM, May EB (2016) Persistence and surface transport of urea-nitrogen: a rainfall simulation study. J Environ Qual 45(3):1062-1070

King MD, Bryant RB, Saporito LS, Buda AR, Allen AL, Hughes LA, Hashem FM, Kleinman PJA, May EB (2017) Urea release by intermittently saturated sediments from a coastal agricultural landscape. J Environ Qual 46:302-310

Kleinman PJ, Church C, Saporito LS, McGrath JM, Reiter MS, Allen AL, Tingle S, Binford GD, Han K, Joern BC (2015) Phosphorus leaching from agricultural soils of the Delmarva Peninsula, USA. J Environ Qual 44(2):524-534

Konieczna I, Żarnowiec P, Kwinkowski M, Kolesińska B, Frączyk J, Kamiński Z, Kaca W (2012) Bacterial urease and its role in long-lasting human diseases. Curr Protein Pept Sci 13(8):789-806

Kostadinova G, Petkov G, Denev S, Miteva Ch, Stefanova R, Penev $\mathrm{T}$ (2014) Microbial pollution of manure, litter, air and soil in a poultry farm. Bulg J Agric Sci 20:56-65

Lv F, Xue S, Wang G, Zhang C (2017) Nitrogen addition shifts the microbial community in the rhizosphere of Pinus tabuliformis in Northwestern China. PLoS One 12(2):e0172382

Maeda K, Hanajima D, Toyoda S, Yoshida N, Morioka R, Osada T (2011) Microbiology of nitrogen cycle in animal manure compost. Microb Biotechnol 4(6):700-709

Metcalf JH, Moore PA Jr, Donoghue AM, Reyes-Herrera I, Arsi K, Woo-Ming A, Blore PJ, Hanning I, Ricke SC, Donoghue DJ (2014) Bacterial content in runoff from simulated rainfall applied to plots amended with poultry litter. Int J Poult Sci 13(3):133-137

Morris DR, Koffron KL (1967) Urea Production and Putrescine Biosynthesis by Escherichia coli. J Bacteriol 94(5):1516-1519

Muema EK, Cadisch G, Röhl C, Vanlauwe B, Rasche F (2015) Response of ammonia-oxidizing bacteria and archaea to biochemical quality of organic inputs combined with mineral nitrogen fertilizer in an arable soil. Appl Soil Ecol 95:128-139

Noguchi K, Nakajima H, Aono R (1997) Effects of oxygen and nitrate on growth of Escherichia coli and Pseudomonas aeruginosa in the presence of organic solvents. Extremophiles 1(4):193-198 
Nygaard TP, Rovira C, Peters GH, Jensen MO (2006) Ammonium recruitment and ammonia transport by $E$. coli ammonia channel AmtB. Biophys J 91(12):4401-4412

O’Toole GA (2011) Microtiter dish biofilm formation assay. J Vis Exp 47:2437

Pechal JL, Crippen TL, Benbow ME, Tarone AM, Dowd S, Tomberlin JK (2014) The potential use of bacterial community succession in forensics as described by high throughput metagenomic sequencing. Int J Legal Med 128(1):193-205

Peterson CN, Mandel MJ, Silhavy TJ (2005) Escherichia coli starvation diets: essential nutrients weigh in distinctly. J Bacteriol 187(22):7549-7553

Potter LC, Millinfton P, Griffiths L, Thomas GH, Cole J (1999) Competition between Escherichia coli strains expressing either a periplasmic or a membrane-bound nitrate reductase: does Nap confer a selective advantage during nitrate-limited growth? Biochem J 344(Pt 1):77-84

Shimizu K (2013) Regulation systems of bacteria such as Escherichia coli in response to nutrient limitation and environmental stresses. Metabolites 4:1-35

Soman C, Li D, Wander MM, Kent AD (2017) Long-term fertilizer and crop-rotation treatments differentially affect soil bacterial community structure. Plant Soil 413(1-2):145-159

Stein LY, Klotz MG (2016) The nitrogen cycle. Curr Biol 26(3):R94-R98

Tuchman M, Rajagopal BS, McCann MT, Malamy MH (1997) Enhanced production of arginine and urea by genetically engineered Escherichia coli K-12 strains. Appl Environ Microbiol 63(1):33-38

van Beilen JWA, Hellingwerf KJ (2016) All three endogenous quinone species of Escherichia coli are involved in controlling the activity of the aerobic/anaerobic response regulator ArcA. Front Microbiol 7:1339

Wang H, Zhang S, Yang L, Chen Q, Yang B (2012). Effects of environmental factors on the soil nitrogen transformation in terrestrial ecosystems. iCBEB 1-25
Wang MM, You D, Ye BC (2017) Site-specific and kinetic characterization of enzymatic and nonenzymatic protein acetylation in bacteria. Sci Rep 7(1): 14790

Warry EN, Khorasani S, Mazanderani A, Sall K (2008) Controlling the growth rate of Escherichia coli by limiting the supply of carbon in an amylose-amylase nutrient system. J Exp Microbiol Immunol $12: 1-6$

Wasik E, Chmielowski K (2017) Ammonia and indicator bacteria removal from domestic sewage in a vertical flow filter filled with plastic material. Ecol Eng 106:378-384

Whitehead RN, Cole JA (2006) Different responses to nitrate and nitrite by the model organism Escherichia coli and the human pathogen Neisseria gonorrhoeae. Biochem Soc Trans 34(Pt 1):111-114

Williams TR, Marco ML (2014) Phyllosphere microbiota composition and microbial community transplantation on lettuce plants grown indoors. MBio 5(4):e01564-14

Yergeau E, Maynard C, Sanschagrin S, Champagne J, Juck D, Lee K, Greer CW (2015) Microbial community composition, functions, and activities in the Gulf of Mexico 1 year after the deep water horizon accident. Appl Environ Microbiol 81(17):5855-5866

Yuan J, Doucette CD, Fowler WU, Feng XJ, Piazza M, Rabitz HA, Wingreen NS, Rabinowitz JD (2009) Metabolimics-driven quantitative analysis of ammonia assimilation in E. coli. Mol Syst Biol 5:302-317

Zhang LH, Chen SF (2015) Influence of different factors on the nitrogenase activity of the engineered Escherichia coli 78-7. World J Microbiol Biotechnol 31(6):921-927

Zhou XQ, Chen CR, Wang YF, Xu ZH, Duan JC, Hao YB, Smaill S (2013) Soil extractable carbon and nitrogen, microbial biomass and microbial metabolic activity in response to warming and increased precipitation in a semiarid Inner Mongolian grassland. Geoderma 206:24-31 